\title{
Does International Investment Law Constitute a Limit or a Treat to the Right of the States to Regulate?
}

\author{
Eman Adel Eid Hassan (1) \\ Ahram Candian University, 6th of October City, Egypt \\ Email: eenglish51@yahoo.com
}

How to cite this paper: Eid Hassan, E. A. (2022). Does International Investment Law Constitute a Limit or a Treat to the Right of the States to Regulate? Modern Economy, 13, 69-78.

https://doi.org/10.4236/me.2022.131005

Received: December 1, 2021

Accepted: January 16, 2022

Published: January 19, 2022

Copyright $\odot 2022$ by author(s) and Scientific Research Publishing Inc. This work is licensed under the Creative Commons Attribution International License (CC BY 4.0).

http://creativecommons.org/licenses/by/4.0/

\section{(c) (i) Open Access}

\section{Abstract}

To identify international investment law as a part of international law control and manage, then to analyze the relationships between foreign investors in host country and the state. And compare its role with the state regulation. using qualitative case study had been explained in the conduct of the research and collecting main data to express the role of international investment law. The researcher contacted some implement cases from UK, US, and China. Due to heavy comparison, after several evaluation of the literature from the UK and US. Some of the findings of the study are: 1) with these explaining the international investment law in mind after begin by describing the main procedural and substantive challenges, we find the limitation of the foreign investment role in providing the protection for the foreign investor against the state regulation; 2) no comprehensive or integrated international treaty on the regulation of foreign investment; 3) international investment law can be deemed as one of the pioneers for protection the investor after conducting an analysis of the role of investment law to prevent the rights of investor in jurisprudence; 4) with expanding of international investment and increasing the number of companies investing abroad in foreign countries, the implementation of the core concepts of public international law has not been deemed adequate to regulate foreign investment.

\section{Keywords}

International, Investment, Law, State

\section{Introduction}

The international investment law has a great role in the trade for the right of foreign investor, but there was a trend to regime that role currently for unprece- 
dented level of public scrutiny. Investment regulation was clearly reviewed by some groups of investors in investment negotiations; it is the spot line on some of the practitioners and academics. This is because the law of foreign investment will be implemented in the state and there were some reflection between both sides, that will be the result of the investor-state dispute settlement (ISDS), which will let the implement with confusion in jurisprudence, it was actually for a main mission of a narrow commercial law.

It will affect the role of public in some countries; it should be integration between the state regulation and the international investment law, to simplify the international implement pronouncing on the rights of foreign investment.

It isn't the same case for the international trade law or international human rights law, the absence of the effective mechanism to enforce the law with its legal power. The implement in a simple way wasn't working, that many countries are terminating their bilateral investment treaties (BITs), there were many cases with disputation facing the investment arbitration. For example, in the case of South Africa, it is systematically terminating in the cases of implementing the international investment law, it happened for all of its BITs against empower the local regulations, to treat the foreign investors cases in its territory.

In the fact, there is a challenge and states face a troubles with the implement of the international investment law with a conflict with its state regulation, the same for Indonesia with the range of 17 out of 64 international investment agreements (IIAs), and Argentina might be at the second level to in denunciation from ICSID. In Latin American countries from ten years ago, half of registered ICSID cases were pending after four years the quarter of the new cases was respondent.

From eight years there were new trends with the support of the United $\mathrm{Na}$ tions in its Conference for trade to increase the role of state with domestic judicial systems that will affect the role of ISDS with a limited resort.

Next, that will need to give an examination of the nature of "getting it right" and its importance with level of enforcement in the sphere of foreign investment. In light of the challenges with the control that role against the government immunity in the state with its regulation as the main problems with the law of foreign investment. The international investment law gives the access to the foreign investor to get his right and enjoy the same benefits which is available to domestic investors. These may need to upload more obligations on the host country to get fair treatment that will bring a challenge to the government of the state to face a legal form in disruption, in the implementing of investor-state dispute settlement (ISDS).

The state under international investment law has many forms of obligations, but the core treatment to the investor is a common treats for most of foreign investor, but actually there was a discussion and negotiation before any decisions related to foreign investment contracts ${ }^{1}$.

${ }^{1}$ FCTC for Law (2019). Why is international investment law relevant to WHO FCTC implementation? FCTC for law, Switzerland. 
It is so important to construct this article to prove that there is a real right for the state to put its regulation, that is the central fact with no argument in that issue, but that isn't also referrers to the absence of the link between it and the international investment law, still actually the discussion like the role in the regulation, that will support the evidence of legal form in the cases in the state to finalize the issue related to the arbitration.

The main contributions of this article were in measuring the costs of the arbitration for the investment dispute in the three countries is considered a loss for the country, so it should be considered in contracts as this cost can be measured as a percentages of the investment and it is highly indicators especially in USA. As it is a challenge in some cases what will control the local law in the host state or the international investment law, especially if the reflection in paying a large amount of money for the investor as a compensation, here the state prefer to enforce the foreign investor to accept the rules of the law in the state when he insists on implementing the international investment law to prevent his rights.

The article is organized as follows, first section for introduction, second a literature review section to explain the latest researches for the immunity and the investment law, third the methodology to compare with the three countries USA, UK and china, fourth the conclusion to sum up the article.

\section{A Literature Review Section}

It was an explanation of the country with the right to regulate (Mann, H., 2002), and that refers to its ability to set rules for the foreign investment according to the investment agreements, and to supervise and control the internal improvement priorities, that will lead to explain the role of the primary right to regulate as a process of protection for the citizen welfare from any future bad impacts, at the end all the investment is equal even it was an international investment not local or domestic.

The article (Dolzer, R. \& Schreuer, C., 2012) aimed to prove that there may be a distinction between the international investment law and the domestic law of the state; it is a classification of the separate points in the legal orders.

There is a central right of the state related to the immunity of the host country (Giannakopoulos, C., 2017), and it should be clear that the regulation in the international investment law cannot reflect the protection of the host country.

the literature gap was at a measuring of the negative effect on the investment gain and the loss of paying a high cost for claim, and this research will fill such a research gap by highlight the percentage of the cost divided to the investment in the three developed countries like USA and UK with an example for emerging countries like china, the research prove that all of them even with their different rate will bear a loss of conflict with the state immunity and the international investment as there were many strategies to develop the fully justify or excuse to act clearly, and it is about the responsibility of the state in that right to regulate. 


\section{Methodology Section (Figure 1 and Figure 2, Tables 1-4)}

When we measure the relation between the cost of claims in the case of dispute

Table 1. ICSID convention and additional facility rules.

\begin{tabular}{cc}
\hline year & Number of cases \\
2015 & 52 \\
2016 & 48 \\
2017 & 53 \\
2018 & 56 \\
2019 & 39 \\
2020 & 58
\end{tabular}

Source: International centre for settlement of investment disputes, report of 2021, world bank group publications, Washington (World Bank Group, 2021).

Table 2. State of nationality of arbitrators for cases in ICSID.

\begin{tabular}{cc}
\hline State & As of December 31, 2020 \\
\hline USA & 262 \\
china & 15 \\
UK & 236
\end{tabular}

Source: International centre for settlement of investment disputes, report of 2021, world bank group publications, Washington (World Bank Group, 2021).

Table 3. A sample of bending cases in 2020 in China, USA and UK.

\begin{tabular}{|c|c|c|c|c|c|}
\hline YEAR & Short case name & country & rules & OUTCOME & summary \\
\hline 2020 & $\begin{array}{c}\text { Asia Phos against } \\
\text { china (agreement } \\
\text { year 1985) }\end{array}$ & china & ICSID & PENDING & $\begin{array}{l}\text { Investments in the } \\
\text { three phosphate } \\
\text { mines in the } \\
\text { schuan province }\end{array}$ \\
\hline 2020 & $\begin{array}{c}\text { Amorrortu } \\
\text { against peru } \\
\text { (agreement year } \\
\text { 2006) }\end{array}$ & USA & UNCITRAL & PENDING & $\begin{array}{l}\text { Investments in } \\
\text { Baspetrol S.A.C a } \\
\text { company operating } \\
\text { in the oil and gas field }\end{array}$ \\
\hline 2020 & $\begin{array}{l}\text { Durres and others } \\
\text { against Albania } \\
\text { (agreement year } \\
\text { 1994) }\end{array}$ & UK & ICSID & PENDING & $\begin{array}{l}\text { Investments a joint } \\
\text { venture holding a } \\
\text { concession contract } \\
\text { for the management, } \\
\text { operation and } \\
\text { maintences of a } \\
\text { container terminal at } \\
\text { the port of Durres }\end{array}$ \\
\hline
\end{tabular}

Sources: UNCTAD (2021), investment dispute settlement navigator, UNCTAD, USA. 
Table 4. Respondent and home states in known treaty-based ISDS cases, 1987-2020.

\begin{tabular}{cccccccc}
\hline Country & $\begin{array}{c}\text { Cases as } \\
\text { respondent } \\
\text { state }\end{array}$ & $\begin{array}{c}\text { Cost } \\
(4.7 \text { million\$ } \\
\text { median })\end{array}$ & $\begin{array}{c}\text { Cases as } \\
\text { home state } \\
\text { of claimant }\end{array}$ & $\begin{array}{c}\text { Cost } \\
(3.8 \text { million\$ } \\
\text { median })\end{array}$ & $\begin{array}{c}\text { Total } \\
\text { cost }\end{array}$ & $\begin{array}{c}\text { Investment } \\
\text { (million\$) }\end{array}$ & $\begin{array}{c}\text { Total } \\
\text { Cost/investment \% }\end{array}$ \\
\hline china & 6 & 28.2 & 8 & 30.4 & 58.68 & 848 & $6.91 \%$ \\
UK & 1 & 4.7 & 90 & 342 & 349.4 & 5799 & $6.02 \%$ \\
USA & 20 & 94 & 194 & 737.2 & 831.2 & 3021 & $27.5 \%$ \\
\hline
\end{tabular}

Sources: https://investmentpolicy.unctad.org/investment-dispute-settlement (Mathew Hodgson, 2021, https://www.worldbank.org).

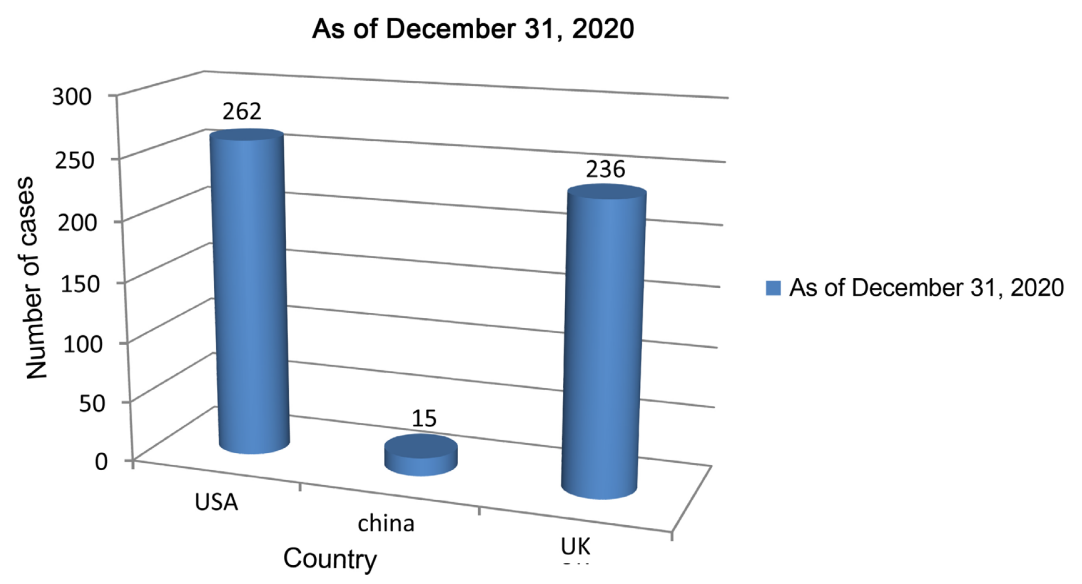

Figure 1. State of nationality of arbitrators for cases in ICSID.

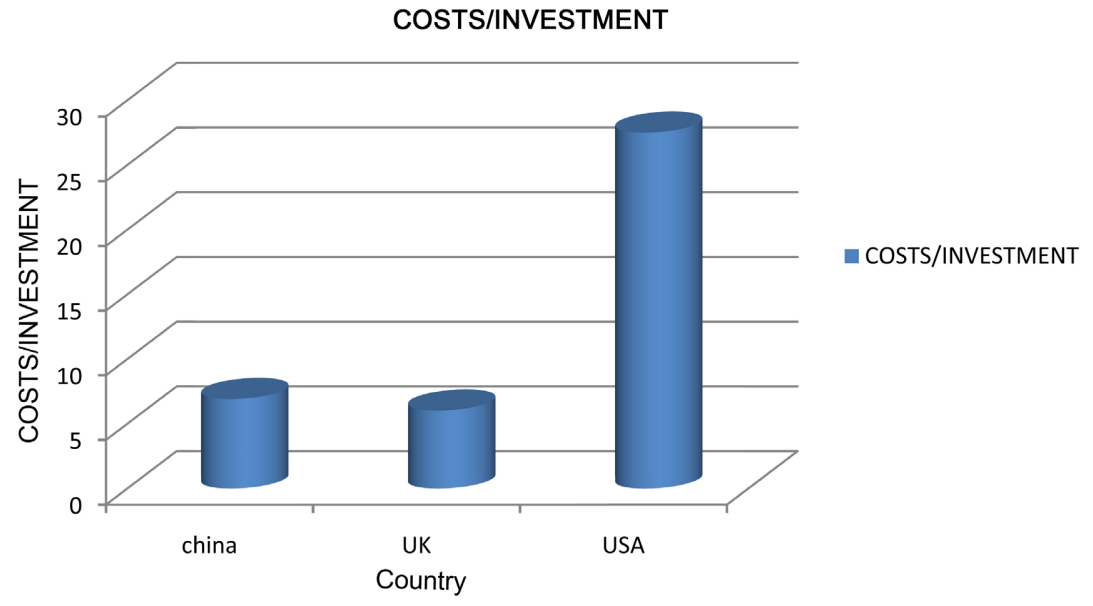

Figure 2. The costs ratio of investment dispute.

between the state for the immunity and the international investment law for preventing the rights of foreign investors and the total investment in the three countries, the results was that USA has the highest rate then china and UK.

\section{Does International Investment Law Constitute a Limit or a Threat to the Right of the States to Regulate?}

The States has its right to regulate, and it is the way to control as public interest 
in the recent years, that regulation with the cooperation of the rules of the international investment agreements, that is a positive regulation to support the law with clear guidance, it is a balance between the interest of the foreign investor and the host country in business, that will help in providing a clear arbitral view of the regulation in the state, there was a gap between the thoughts and concepts, the country has the power to set the rule, it is maybe hard to recognize the role of the country in the light of international investment law, the action of the country in that trend is critical with great concern.

The international investment law was a trend to put the main principles of rules and instrument to control the relationship between the investor from foreign countries and the state relations in some cases it is a regional rule or multilateral instrument. It is a role of judging the international investment community, that will affect the government rules or its regulation in the trade with foreign investment.

Investment through the cases of arbitration has supported the concepts of justice and fairness, rules-based on that system will develop the rule of law, that should aspect the institutional respect of the state in empowering the authorities as a whole in the regulation system. That will be appeared in some real cases, which in reflecting that long term result as an adverse effect or disadvantages of the power of regulation in the host country ${ }^{2}$.

There were some troubles related to the strong relationship between the international investment law and the negative effect on the host state's sovereignty, and it will lead to minimizing its role, which is a pressure on the investment agreements in the host country. The international law prevent the rights of the foreign investor, and if the state broke the investment trade that will affect badly on the foreign investment, that is referred to the sovereign power and how the state can use such a power in putting the investor in a bad situation. It shouldn't be any reflection as the state should encourage the foreign investment and prevent the right of the investors and implement the investment agreements with its commitment to take the sustainable relationship with the investor and give a good image to the environment of the investment in the country as a resource of foreign currency and provide job opportunities, that will support the economy in the state, but in the real implement that unfair implement can be in some cases, the state shouldn't use their sovereign power in the political or economic or legal form, it should be a limit for using that right in the light of sovereign immunity in the host state.

The balance in that trend should be between the enforcement of the host country and the roles of the international investment law, claiming the sovereign immunity should reflect the respect of the international law, the interest of both the host country and the foreign investor should work together in the same line

${ }^{2}$ Stephan W. Schill (2017). International investment law and the rule of law, Amsterdam law school legal studies research paper No. 2017-18 Amsterdam center for international law No. 2017-15, University of Amsterdam. Netherland, 2017. 
that should be without any confliction in the contract ${ }^{3}$.

The state encourages the foreign investment and in the favor of that trend, it signs the BITs and IIAs, the state accepts that agreements to create a climate for more investment, that will increase the foreign direct (FDI). But is it was a good decisions and had a positive impact on the increasing the foreign investment in fact that wasn't happened, it was not promote to more investment, because of the limited enforcement of law of foreign investment through regime.

Investment Arbitration was increased with an increase in cases of investment arbitrations, the cases over time have been growing, and it recently, it was against the system of state regulation.

The arbitration was a result of failing in the implementation of the contract, there was a chance to choose a third party as arbitrator according to the items in the contract as each party can select anyone but the interpretation for the articles in the contract was a big problem for the arbitrator, the treatment of the law serve only individual side for investment treating, it is better to be in nature for any public problems in the contract as the state was a main party in the contract and the dispute was a result of conflict in the state interest and the policy, in the local court for the arbitration in the state, the host country can implement its rule, but the case of investment tribunals, the role of the state will be reduced, the two party will follow the international investment law, there was a reference from the cases in the implement of the other countries in the similar cases.

\section{Can We Protect the Regulatory Power of the State?}

The state should change its rules in the domestic landscape foe economic, political, environmental and landscape to adapt to the investment law for the international implement, it is a case of implementing BITs and IIAs, that should prevent the foreign rights in the investment as a promise in the contract when it starts a new investment, the foreign rights affected by the activity of the state, the regulation in the state will be limited according to encourage the foreign investment, it is accepted the limitation of its power to gain the foreign investment, the state agree to attract the foreign investment with the limited power of its regulation, the right situation in the success in implement the balance between the power of regulation in the state and the power of foreign investment, in the host country the foreign investor need to prevent his rights and the protection of the investor rights need to give up some of the protection of the regulatory power of the state, that balance between the two party will be a benefit for the rights of the investor.

\section{The Costs of Investment and Arbitration}

The investment in the host country need a lot of many, it reflect the investment in millions or even billions, the high cost here reflect the need for protection of

\footnotetext{
${ }^{3}$ Nasser Mehsin Al-Adba (2014). The limitation of state sovereignty in hosting foreign investments and the role of investor-state arbitration to rebalance The investment relationship, The University of Manchester, UK.
} 
the rights, the disputation has a large cost also and should be considered in the investment cost and should be in the account before signing any international investment contract, the Russia example was a signed case for the high cost of the arbitration as the claim had a high of the Permanent Court of Arbitration, and protection of the foreign investor need a high cost of legal in individual disputes, that reflect the empower of judgment cases ${ }^{4}$.

\section{Investment Law as Economic Governance: A New Paradigm}

There were many lessons from the trade law crisis, it was a sort of the conflict in the trade system and the social issue, that lessons in the ability of change for the main intuition inform, the facing of the challenge, the parties dissatisfied with the fact of stakeholders with different institutional and doctrinal issues of trade law, it should learn politically from the WTO system, the needs for the main change as possible in the regulation implement.

The same case at investment, the developing prominence for that reflects the great importance of Foreign Direct Investment (FDI) in supporting in the international economy as a whole. In that sense, it reflects the important of the international investment regime in increasing global investment capital at a widescale. But, the explaining of these issues equally clarify the developing recognition that supervision an international investment trend involves far more than technical issues for national treatment standards.

Investment had awareness of the culture and the main social issues in the trend of responsibilities at the host states, capital unable to manage that individually, it is also facing the problem in trade law in its implementation, it is depending on the understanding of the international trade law with the implement in the institution about the economic flows, the international law focused on the economic flows, it is a liberalizing view, it is a debate about the problem in trade with a highlight of the fact of trade and trade law with a complex view of liberalizing, the local trading system turned into a global one in an emerging system for a global structure in trade with a constraints and defects in the government's system, it is a social issue also to see the public making in the system of government with a commercial dispute to support the justice and the rule of regulation in the respect of the economic relation, it is a compliance of the investment capital, the state use its power of immunity to prepare a frame for trade in public law to control the economic activity using the sovereign power while the international law is governance, the judge will be for the foreign investment capital and its regulation with their judge rule, it should be developed to be more integrated with the rules of investment in the current regulation in the host countries. The institutional mechanism is important to evaluate the resulting of the dispute but it shouldn't be the frame for international trade, it should be more flexibility to adapt with the international law, it should include a legal power of

${ }^{4}$ Nicolette Butler (2017) The future of international investment regulation: towards a world investment organization? Springer link articles, Germany. 
the state party in the host state's decisions, the state should develop the regulation frame with a range of political and distractive decisions enhancing the power and the rights to be quite familiar to the local law.

In economic law there is a vision in the focusing on the private actions to set/LL/the arrangement in the contract law in many fields in employment law, competition law, securities law, etc., the structure in the economic law is similar to the international investment regime, and potential investment law reforms.

The problem between the investors and the government in a multinational actors in a frailer of knowledge in a political system in justify of the investment treaty according to the principle of fairness in the main system, in the contribution of the investment should be at the priority of the decision for the host country.

\section{Conclusion}

The main systemic can contribute in the current legitimacy crisis in foreign investment. The key response in trade law to its own parallel crisis was for the system to accept the consequences of its success and embrace its role in exercising governance over the allocation of global economic resources. As has been the case with trade, for investment this shift will have two key dimensions: a normative perspective (justice), and a set of institutional implications (governance rules) $)^{5}$.

The policy implicated was in evaluating the cases in the light of two sides, first for the state and its immunity, second the foreign investor, the international investment role in the governance system is deficient; it is a right to set a condition with the power of capital with an action problem which cannot play an effective role in the host state, the investment law treats the private ordering in commercial arbitration the public nature of the rules and the effect of the regulation and the economic resources, it would play recognized principles of distributive justice, the public authority allocate wealth toward the rights and resources in the taxation system and banking system.

The literature gap and how this research will fill such a research gap should be discussed at the end of literature. When we measure the relation between the cost of claims in the case of dispute between the state for the immunity and the international investment law for preventing the rights of foreign investors. And the total investment in the three countries, the results will be that USA has the highest rate then china and UK.

\section{Conflicts of Interest}

The author declares no conflicts of interest regarding the publication of this paper.

${ }^{5}$ Garcia, F. J., Ciko, L., Gaurav, A., \& Hough, K. (2015). Reforming the international investment regime: lessons from international trade law. Journal of International Economic Law, 18 (4), 861-892. 


\section{References}

Al-Adba, N. M. (2014). The Limitation of State Sovereignty in Hosting Foreign Investments and the Role of Investor-State Arbitration to Rebalance the Investment Relationship. Economic Thesis, Manchester: The University of Manchester.

Butler, N. (2017). The Future of International Investment Regulation: Towards a World Investment Organization? Netherlands International Law Review, 64, 43-72. https://doi.org/10.1007/s40802-017-0082-5

Dolzer, R., \& Schreuer, C. (2012). Principles of International Investment Law. Oxford University Press. [https://doi.org/10.1093/law/9780199651795.001.0001

FCTC for Law (2019). Why Is International Investment Law Relevant to WHO FCTC Implementation? FCTC, Switzerland.

Garcia, F. J., Ciko, L., Gaurav, A., \& Hough, K. (2015). Reforming the International Investment Regime: Lessons from International Trade Law. Journal of International Economic Law, 18, 861-892.] https://doi.org/10.1093/jiel/jgv042

Giannakopoulos, C. (2017). The Right to Regulate in International Investment Law and the Law of State Responsibility: A Hohfeldian Approach. Economic Thesis, Singapore: National University of Singapore. https://doi.org/10.2139/ssrn.2962686

Hodgson, M. (2021). Costs, Damages and Duration in Investor-State Arbitration, British Institute of International and Comparative Law, UK.

https://investmentpolicy.unctad.org/investment-dispute-settlement

Mann, H. (2002). The Right of States to Regulate and InternationalInvestment Law, International Institute for Sustainable Development, Canada.

Schill, S. W. (2017). International Investment Law and the Rule of Law, Amsterdam Law School Legal Studies Research Paper No. 2017-18 Amsterdam Center for International Law No. 2017-15. Amsterdam: University of Amsterdam.

UNCTAD (2021). Investment Dispute Settlement Navigator.

World Bank Group (2021). International Centre for Settlement of Investment Disputes, Report of 2021. Washington. 